\title{
Politisk Revy, redaktionen Solsjenitsyns sag og arbejderklassens
}

Så er den gal igen med Solsjenitsyn.

Den seneste roman om fangelejre og terror i Sovjet er udkommet. I vesten, altså. Til gengæld udsættes forfatteren i sit hjemland for stadig mere bitre angreb.

Selv appellerer han på sin side til 'den vestlige opinion' om støtte. Angiveligt for derved at forhindre angrebene i at gå over i hånd gribeligheder.

Hvilken stilling skal socialister tage til disse appeller?

Solsjenitsyn er ikke en socialistisk kammerat, der er kommet i vanskeligheder, fordi han i sin bog har villet forsvare den sovjetiske arbejderklasses interesser.

På det grundlag kunne man f.eks. uden videre erklære sig solidarisk med f.eks. historikeren Medvedev, der for et par år siden var tvunget til at lade sin kritiske bog om stalinismen, 'Let History Judge', publicere i vesten.

Men altså ikke med Solsjenitsyn. Han er, hvad grundliggende holdning angår, nærmest en politisk modstander. Det ideologiske og klassemæssige grundlag for den kritik, han fremfører i sin bog, er nærmest den før-revolutionære bondes. Ikke proletariatets.

Det vil i den nuværende situation være fordummende ikke klart at fasthoIde, hvad Jan Myrdal har beskrevet som Solsjenitsyns binding til "nationalistiske gruppers storrussiske og konservative forestillinger «.

Ikke desto mindre gik Myrdal i samme artikel i Dagens Nyheter fra september sidste år kraftigt ind for, at vi som vestlige socialister støttede osse højre-oppositionelle som Sacharov og Solsjenitsyn. Tilsvarende har Folkets Dagblad i Peking for første gang benyttet lejligheden til at tage afstand fra Sovjets behandling af alle politiske afvigere. Og det i et sprog så voldsomt, at vi her vil afstå fra citater - for ikke at blive beskyldt for at være antikommunistiske levn fra den kolde krig.

Desuden har repræsentanter fra de kommunistiske partier i Frankrig, Italien, Sweitz og Spanien på en pressekonference i Genf erklæret, at deres partier var imod den sovjetiske regerings beslutning om at forbyde udgivelsen af Solsjenitsyns bøger i Sovjetunionen, selv om han blev mere og mere reaktionær. 
Naturligvis kan vi som socialister ikke begrunde vores stillingtagen ud fra gængse borgerlige forestillinger om at forfattere, det er nogle særligt vigtige væsener, hvis ytringsfrihed skal beskyttes $\mathrm{i}$ ganske særlig grad. I åndslivets og den diffuse humanismes navn. Hverken vi eller forfattere $i$ almindelighed er brødre med alle $i$ åndens rige, - så længe vi ikke er det $\mathrm{i}$ virkelighedens. DKPeren Lars Bonnevie brækker sig i Information d. 5.2. med rette over den 'åndslivets hellige alliance', der altid mobiliseres ved lejligheder som denne.

Det er åndsarbejdere, der kan hyle op om ytringsfrihedens betydning, når det gælder en bror $\mathrm{i}$ ånden som Solsjenitsyn. Men gælder det f.eks. det forhold, at et flertal $\mathrm{i}$ dette land mindst otte timer daglig må afhænde de fleste borgerlige frihedsrettigheder til arbejdsgiveren sammen med deres arbejdskraft - ja, så er de hverken interesserede eller forargede.

$\mathrm{Og}$ vores lokale forfatterforening. Skal der 'slås vagt om' Solsjenitsyn, så strutter den af handlekraft. Derimod blev den grebet af akut handlingslammelse, da det drejede sig om den psykiske tortur af skribenten Ulrike Meinhof $\mathrm{i}$ vesttyske fængsler.

Skråt op i røven med sådant et åndsliv og dets 'humanisme'.

Men vi kan ikke følge Bonnevie $i$, at løsningen bare består $i$ at skifte den ene åndsarbejder ud med den anden: at snakke om Pablo Neruda i stedet for Solsjenitsyn.

Man kan jo snakke om så meget. Vi foreslår i stedet, at man snakker om arbejderklassen. Der plejer socialister at begynde. I det her tilfælde: Hvor ligger den sovjetiske arbejderklasses interesser i Solsjenitsyns konflikt med statsmagten?

Det spørgsmål kan ikke svares alene ud fra Solsjenitsyns tydeligt markerede klasseposition.

Det drejer sig i dette perspektiv ikke så meget om enkeltpersonen Solsjenitsyn. Afgørende er derimod, at Solsjenitsyns konflikt med statsmagten overhovedet markerer den manglende mulighed for åben, offentlig kritik og diskussion, enhver sovjetborger er underlagt $i$ dag.

Dermed er osse den sovjetiske arbejderklasse berøvet et af de vigtigste midler til organiseringen af sig selv som klasse.

$\mathrm{Vi}$ erindrer om, at den europæiske arbejderklasses oprindelige konstituering som klassebevidst klasse bl.a. kom i stand ved udnyttelse af formelle borgerlige frihedsrettigheder $i$ etableringen af en åbent diskuterende og kritiserende proletarisk offentlighed. (Tænk blot på den engelske arbejderklasses frodige udnyttelse af pressefriheden $\mathrm{i}$ begyndelsen af 1800-tallet.) 
En sådan proletarisk offentlighed er langt fra det samme som den forstenede parti-offentlighed, der i dag er eneherskende i Sovjet. Tværtimod er denne et led i undertrykkelsen af arbejderklassens egne muligheder for kritisk at forarbejde historiske og aktuelle erfaringer.

Solsjenitsyns ret til at ytre sig kan ikke være mere vigtig end en hvilken som helst sovjetarbejders. Men i selve sin kamp for overhovedet at få lov til at ytre sig uantastet i sit hjemland kæmper han altså osse objektivt for visse af den sovjetiske arbejderklasses kortsigtede interesser.

Proletariatets objektive interesse på dette område liggęr overalt $\mathbf{i}$ den størst mulige forvandling af den blot formelle borgerlige ytringsfrihed til reel ytringsmulighed. Ikke i noget, der ikke engang kommer på højde med den formelle borgerlige frihed. Sker det, er det osse proletariatet, der i sidste ende bliver undertrykt.

En støtte til Solsjenitsyn fra socialistisk side må bygge på en præcisering af dette generelle politiske perspektiv.

Når det er sagt, så bør det dernæst tilføjes, at netop bøger som den næunte af Medvedev, men osse Solsjenitsyns, i kraft af deres emme er af stor umiddelbar interesse for den sovjetiske arbejderklasses bearbejdning af dens egne historiske erfaringer.

De rystende forhold, Solsjenitsyn skildrer, er ikke udelukkende digt og fri fantasi. De har været blodig virkelighed. Osse for dele af det sovjetiske proletariat.

Trods den klassemæssige hildethed, trods mange unøjagtigheder er selve Solsjenitsyns stof af en sådan art og uafviselighed, at det forlanger en åben socialistisk diskussion.

Det er, hvad den konkrete bog angår, denne diskussion, der er $\mathrm{i}$ proletariatets interesse. Ikke parti-offentlighedens forsøg på fortrængning. Og til disse overvejelser kommer endnu én, der denne gang mere direkte angår os selv som socialister i dette land:

Medmindre vi i situationer som denne fastholder det generelle politiske perspektiv, der blev opridset $\mathrm{i}$ det foregående, vil det betyde en taktisk blottelse $\mathrm{i}$ de kommende års kamp mod den stigende statslige repression mod venstregrupper overalt i den vestlige verden.

Det argument var Jan Myrdals begrundelse for, at vi skulle støtte sådan en som Solsjenitsyn. Myrdal talte om, at den afspænding, "som nu er ved at stivne i fast form ikke bliver folkenes afspænding, men blot et gendarmernes Europa. Et gendarmernes Europa fra Atlanten til Ural«.

Der er ingen tvivl om, at den aktuelle Solsjenitsyn-affære, som er 
kommet til efter Myrdals opråb, er en stor irriterende ko på isen midt $i$ en tilnærmelse mellem først og fremmest USA og Sovjet. $\mathrm{Og}$ for begge parter, når det kommer til stykket. F.eks. kunne Information i januar offentliggøre et åbent brev til Solsjenitsyn fra en fremtrædende amerikansk industrimand. Det fortalte om alt det, forfatteren var ved at ødelægge med sin bog!

Selvfølgelig ligger der netop den slags hensigter bag Solsjenitsyns valg af tidspunkt og omstændigheder i forb.m. offentliggørelsen $i$ vesten. Han har ud fra sine forudsætninger været bekymret over nøjagtig de udsigter, Myrdal talte om - bortset fra at hans horisont givetvis har været begrænset til Sovjet.

Men igen: Er det i să fald bare sine egne umiddelbare interesser, han derved har hyppet?

Politisk Revys redaktion

15.2.1974 